\title{
Immunity against COVID-19: Potential role of Ayurveda: A Review
}

Mula Ram Suthar ${ }^{1}$, Manjry Anshumala Barla ${ }^{2}$, Rakesh Roushan *3.

${ }^{1}$ M.D. Scholar, Department of Kriya Sharir, CBPACS, Govt. of NCT Delhi, India.

${ }^{2}$ Senior Medical Officer (Ay.), Directorate of AYUSH, Govt. of NCT Delhi, India.

${ }^{*}$ Assistant Professor, Department of Kriya Sharir, CBPACS, Govt. of NCT Delhi, India.

\section{ABSTRACT}

The Severe acute respiratory syndrome corona virus 2 (SARS-CoV-2) is an infectious disease caused by coronavirus disease 2019 (COVID-19) and has affected people's lives globally, since first case was detected in Wuhan, China in December 2019. The coronavirus pandemic has turned the world's attention to the immune system, the body's defense mechanism against disease. Concept of Ojas is well explained in all ayurvedic classics, in modern perspective it is considered as immunity (Vyadhikshamatava). Ojas is necessary for well-being of the body, and mind. In Ayurveda textbook, the epidemics and along with their management are discussed under the term of Janapadodhvansa. The preventive and curative treatments for communicable diseases of the Janapadodhvansa (epidemics) are Panchkarma (five bio-purification therapies), Rasayana Chikitsa (rejuvenation treatment), Achara Rasayana (good conducts), and migrate to the place, free from communicable diseases. The intake of all types Rasayanas leads to increase of Ojas and reduce all psychological (mainly stress and emotional) disorder, thereby causes increase immunity responses and help to fight against covid-19.

Key Words: Ayurveda, Covid-19, Immunity, Janapadodhvansa, Ojas, Rasayana Chikitsa.

Address for correspondence: Dr. Rakesh Roushan, Assistant Professor, Department of Kriya Sharir, CBPACS, Govt. of NCT Delhi, India. E-Mail: rakesh.roushan45@gov.in

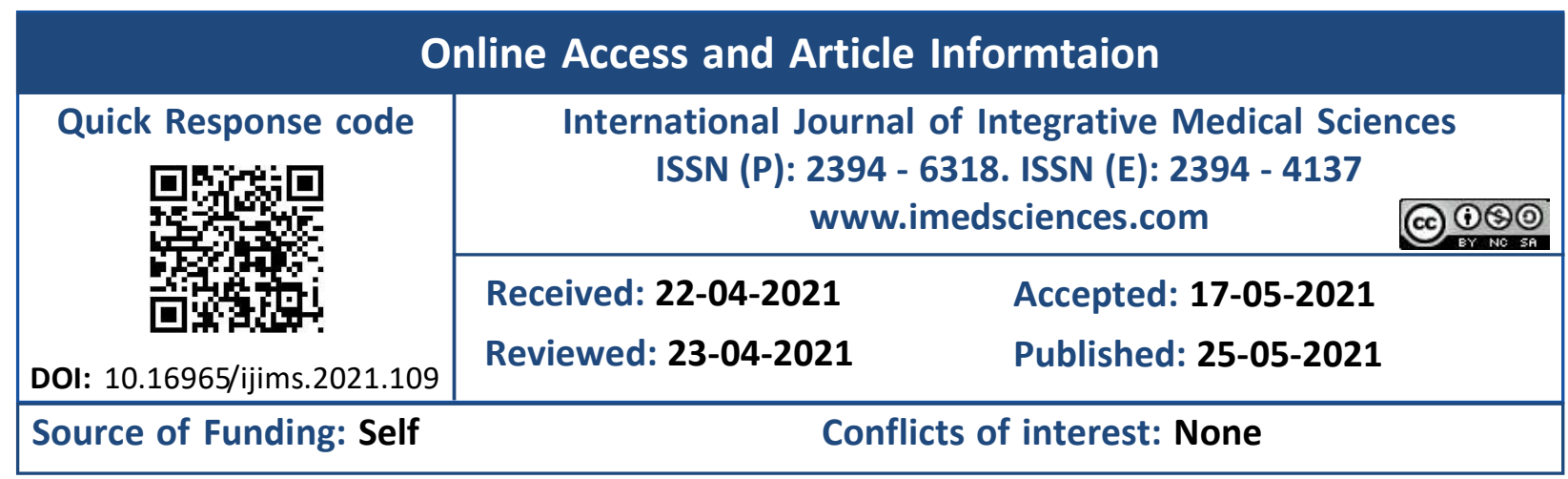

\section{INTRODUCTION}

The coronavirus disease 19 (COVID-19) epidemic is unprecedented in several aspects and has challenged health care systems across the world. The coronavirus epidemic has turned the world's attention to the immune system, the body's defense mechanism against disease- causing bacteria, viruses and other organisms that we touch, ingest and inhale every day [1]. With the view to elucidating the Ayurvedic concept of immunity, an attempt has been made to arrange the classical literature systematically and screening them in the light of modern perspective. The all Ayurvedic classical texts clearly stated word Bala is used as a synonym of Ojas and also for immunity (Vyadhikshamatava). Ojas is necessary for well-being of the body, and mind. Acharya Charak has stated Bala (Immunity and Strength) is of three types- Sahaja bala (natural), Kalaja bala (chronobiologic), and Yuktikrita bala (acquired). The assessment of Bala (physical strength) of the person is done by Anumana (inference) the capacity of an individual to do physical exercise (endurance) [2]. This suggests that the body's immune system plays a critical role in disease development. The COVID-19 crisis has led to high levels of psychological distress and significant impact on mind and soul; especially in 
healthcare workers, frontline workers, and among general population.

Role of Ayurveda in Contagious Diseases: For thousands of years, Ayurveda evolved through a scientific inquiry between Guru and disciple, involving the human-beings or societies (loka). The ancient Ayurveda textbook Charaka Samhita, stated about epidemic management and defines immunity as the ability to preventing and arresting the progression of disease for maintaining homeostasis. It appears that most early cases had a history of contact with the original market for seafood, but the disease has now advanced to be transmitted through human to human contact [3]. Thus, this disease is considered as Communicable, both contagious and infectious diseases.

Janapadodhvansa is temporary of high incidence or a widespread occurrence of an infectious disease in a community at a particular time (Kala). In the present scenario, spreading of airborne SARS cov-2, is very quick and affecting a large number of people in the community. In Ayurveda, it is mentioned air is one of the route for spreading of contagious disease. Trisha et al 2021 concluded, there is consistent, strong evidence that SARS-CoV-2 spreads by airborne transmission. Although other routes can contribute, they believed that the airborne route is likely to be dominant; the public health community should act accordingly and without further delay [4]. Ten streams of evidence collectively support the hypothesis that SARS-CoV-2 is transmitted primarily by the airborne route [5]. Asymptomatic or pre-symptomatic transmission of SARS-CoV-2 from people who are not coughing or sneezing is likely to account for at least a third, and perhaps up to $59 \%$, of all transmission globally and is a key way SARS-CoV-2 has spread around the world [6]. Viable SARS-CoV-2 was identified in air samples from rooms occupied by COVID-19 patients in the absence of aerosol-generating health-care procedures [7].

In Ayurveda textbook, the epidemics are discussed under the term of Janapadodhvansa [8] by Acharya Charaka and Maraka by Acharya Sushruta. Janapadodhvansa literally means mass death in communities. The Epidemics and outbreaks of highly communicable diseases have destroyed mankind since time immemorial. Though a community may be different with respect to the constitution and other characteristics of its individuals, there are other common factors which often get adversely affected, resulting in simultaneous outbreak of diseases having analogous symptoms that destroy communities. Acharya Sushruta has mentioned the diseases like Kustha (skin diseases), Jwara, Shosha(tuberculosis), Netrabhisyand (conjunctivitis), and other Aupasargika roga (alike infectious and communicable diseases) spread from human beings to human beings due to Prasanga (intimate relationship), Gatra Sansparsha (direct contact of the body), Nishwasa (breathing or airborne),Sahabhojana (eating together), Sahashayana (sleeping together), sharing and using of others clothing's, garlands and cosmetics etc. [9]. Acharya Dalhana has mentioned that symptoms like Kasa (cough), Swash (breathlessness), Pratisayay (catarrh), Gandhagyan (loos of smell), Bhrama (vertigo), Shiroruka (headache), jwar (fever), will occur after the entry of contaminated air through the Nasarandhra (nasal opening) [10] and Twagnidriya (skin) and these symptoms are similar to clinical features of COVID-19.

The Symptoms of COVID-19 are observed after infections, Common symptoms include headache, fever, loss of smell and taste, nasal congestion, rhinorrhea, cough, muscle pain, sore throat, fever, diarrhea, and breathing difficulties. These Symptoms begin one to fourteen days after exposure to the virus. The main pathway of virus entry and transmission is respiratory droplets that are expelled and absorbed by the mucous membranes, especially the nasal and larynx mucosa, COVID-19 spreads readily via person-to-person contact [11].

General treatment in Epidemics: In classical Ayurvedic literature, the communicable diseases are mentioned under Janapadodhvansa (communicable diseases affecting an entire community); Vitiation of Vayu (air), Udaka (water), Desha (land) and Kala (season) causes development of pandemic in the janpada. 
The preventive and curative treatments for communicable diseases of the Janapadodh vansa (epidemics) are Panchkarma (five bio-purification therapies), Rasayana Chikitsa (rejuvenation treatment), Achara Rasayana (good conducts), and migrate to the place, free from communicable diseases.

Ayurveda in Enhancing Immunity against Contagious Diseases: The Aims of Ayurveda is to preserve the health of the healthy and cure the disease of the unhealthy. Acharya charak in Swastha Chatushka has explained the important guidelines to be followed by healthy individuals to maintain their health. Acharya charak has classified the Bheshaja (Therapeutics) into two categories; one is Svasthasyaurajakr (that which promotes strength and immunity in the healthy), second is Artasyaroganuta (that which alleviates disorders). Acharya charak has explained sixty three Rasayana formulations and fifty Vajikarana formulations to promote health and immunity. A large number of formulations has been explained by Acharyas for alleviation of disease and disorders.

Rasayana means rejuvenation and anti-ageing therapies in Ayurveda. The Rasayana essentially useful for nutrition, rejuvenation, longevity, immune-enhancing and geriatric health care. All Rasayanas formulations are Ojovardhaka in nature i.e., promoter of immune strength in the body, imparting Vyadhikshamatva i.e., immunity in the body. Enhancement of immunity plays a significant role in maintaining optimum health and preventing such communicable diseases. Building a strong immunity is the need of the period to fight this battle against the coronavirus. For the prevention of diseases, immunity or Vyadhikshamatva is a significant concept developed in Ayurvedic literature. All measures explained under Achara Rasayana helps in the improvement of the mental health.

In response to the COVID-19 crisis, the Indian government released a set of guidelines, developed based on the opinion of $16 \mathrm{emi}$ nent Vaidya's (traditional doctors), entitled "Ayurveda's immunity boosting measures for self-care during the COVID-19 crisis", and made them available to the public (https:// www.ayush.gov.in/docs/123.pdf) [12]. These guidelines listed ten measures that were aimed at positively enhancing immunity against infection, though without any specific claims being made with reference to COVID-19.

In conclusion, Communicable above disease (COVID 19) is an outbreak; it spreads readily via person-to-person contact and spreading of respiratory droplets. If someone has good immunity power, the chances of becoming infected will be low, even if the person with good immunity found positive for covid-19, the mild intensity of disease progression and symptoms may occur; and he will easily recover from the infection because of intact immunity power of body. If someone has any co- morbidity, the chances of becoming infected will be more, the moderate and severe intensity of disease progression and symptoms may occur; and he will not easily recover from the infection because of weak immunity power of body. Therefore, the Ministry of AYUSH, Government of India has issued guidelines listed ten measures that were aimed at boosting immunity against Covid-19 infection, though without any specific claims have received the potential Psychoneuroimmune responses. The potential Psychoneuroimmune responses are based on the Rasayana Chikitsa. These all benefits like as longevity, memory, intelligence, freedom from illness, youthfulness, excellence of lustre, complexion and voice, optimum strength of physique and sense organs, perfection in deliberation, respectability and brilliance etc. it is dependent on the Rasayana Chikitsa (rejuvenation treatment) [13].

The intake of all types Rasayanas leads to increase of Ojas due to which immunity increases in body up to the gross level; due to increase immunity responses reduce the All psychological (mainly stress and emotional) disorder, whereby help to fight against covid19 pandemic. Acharya Charak has explained Vishadau Rogavardh-ananam it means grief (mentally fear) is prone for Aggravation of diseases thereby suppress the immunity level. This review concludes Ayurveda has potential 
role in the development of immunity and prevention of coivd-19.

\section{REFERENCES}

[1]. Golechha M. Time to realize the true potential of Ayurveda against COVID-19. Brain, behavior, and immunity. 2020 Jul; 87:130.

[2]. Sri Chakrapani, TrividhaRogaVisheshaVijnaniya Vimanadhyaya. In: Kushwaha HC, editors. Ayurveda deepika on Charaka Samhita. Revised edition. Varanasi (India): Chaukambha Orientalia; 2009;622-628.

[3]. Zhou, P., Yang, XL, Wang, XG. et al. . A pneumonia outbreak associated with a new coronavirus of probable bat origin. Nature. 2020 Mar; 579(7798):270-273. DOI: https://doi.org/10.1038/ s41586-020-2012-7

[4]. Greenhalgh, Trisha et al. Ten scientific reasons in support of airborne transmission of SARS-CoV-2. The lancet 2021. Published Online: April 15, DOI: https://doi.org/10.1016/S01406736(21)00869-2 (preprint).

[5]. Morawska L, Milton DK. It is time to address airborne transmission of coronavirus disease 2019 (COVID-19). Clinical Infectious Diseases. $2020 \mathrm{Nov}$ 1;71(9):2311-3. DOI: https://doi.org/10.1093/cid/ ciaa939

[6]. Johansson MA, Quandelacy TM, Kada S, Prasad PV, Steele M, Brooks JT, Slayton RB, Biggerstaff M, Butler JC. SARS-CoV-2 Transmission From People Without COVID-19 Symptoms. JAMA network open. 2021;4(1):e2035057. DOI: 10.1001/ jamanetworkopen.2020.35057

[7]. Lednicky JA, Lauzard M, Fan ZH, Jutla A, Tilly TB, Gangwar M, Usmani M, Shankar SN, Mohamed K, Eiguren-Fernandez A, Stephenson CJ. Viable SARSCoV-2 in the air of a hospital room with COVID-19 patients. International Journal of Infectious Diseases. 2020;100:476-82. DOI: https://doi.org/ 10.1016/j.ijid.2020.09.025
[8]. Sri Chakrapani, Janpadodhdavanshiniya adhyaya. In: Kushwaha HC, editors. Ayurveda deepika on Charaka Samhita. Revised edition. Varanasi (India): Chaukambha Orientalia; 2009;608-621.

[9]. Sushrut. Nidana Sthana, Kustanidana adhyaya. In: Shastri A.D. (Eds.), Ayurved Tatvasandipika on Susruta Samhita: Revised edition. Varanasi, India: Chaukhamba Sanskrit Sansthan 2016;319-325.

[10]. Sri Dalhan. Ritucharyamadhyaya. In: Trikam Y, editors. Nibandha Sangraha on Sushrut Samhita. Revised edition. Varanasi (India): Chaukhamba Sanskrit Sansthan; 2009;26-30.

[11]. Recalcati S. Cutaneous manifestations in COVID19: a first perspective [published online March 26, 2020]. J Eur Acad Dermatol Venereol. DOI: https:/ /doi.org/10.1111/jdv.16519

[12]. Rajkumar RP. Ayurveda and COVID-19: where psychoneuroimmunology and the meaning response meet. Brain, behavior, and immunity. 2020 Apr 22. DOI: https://doi.org/10.1016/ j.bbi.2020.04.056

[13]. Rawat, Neha \& Roushan, Rakesh. Chyavanaprasha Rasayana; Trusted Armour against Diseases-A Critical Review. 2019;8:304-310.

How to cite this article: Mula Ram Suthar, Manjry Anshumala Barla, Rakesh Roushan. Immunity against COVID-19: Potential role of Ayurveda: A Review. Int J Intg Med Sci 2021;8(3):989-992. DOI: 10.16965/ijims.2021.109 